\title{
Documentation and phytochemical screening of wild vegetables from Siang District of Arunachal Pradesh, India
}

\author{
Jami Nyitan ${ }^{1}$ and Arup Kumar Das \\ Department of Botany, Rajiv Gandhi University, Doimukh-791112, Arunchal Pradesh, India. \\ ${ }^{1}$ Corresponding author: E-mail: jaminyitan@gmail.com
}

[Received 30.11.2018; Revised 15.12.2018; Accepted 19.12.2018; Published 31.12.2018]

\begin{abstract}
The Siang District is located in the foot hills of Arunachal Pradesh and is unique in having rich diversity of wild food plants. The local rural communities depend on wild food plants as food supplements. The present study enumerated 28 wild leafy vegetables shown in tabular form with botanical name, local name, family, mode of consumption $\&$ medicinal uses. The consumption and utilization of wild leafy vegetables should be considered as food resource and is also a part of traditional cultural heritage. The study also includes phyto-chemical screening of five wild vegetables to assess the presence of secondary metabolites.
\end{abstract}

Key words: Documentation, Phytochemical Screening, Wild vegetables, Siang District, Arunachal Pradesh.

\section{INTRODUCTION}

The term 'wild vegetable' plant is mostly used by ethnobotanists in different publications, but its meaning is not very clear. The word "wild" refers to plants grow ins natural vegetation without being cultivated. Those are not domesticated or cultivated by human being but grow itself in the wild. These 'wild edible plants' are extremely important in the livelihood strategies of tribal people (Yesodharan \& Sujana 2007). These also serve as nutritional and health supplement for tribal people in rural areas (Sundriyal \& Sundriyal 2001; Maikhuri et al. 2004; Reddy 2012). Besides being used as food supplement, wild vegetables also make significant contribution in fulfilling the nutritional requirement of local communities throughout the year (Grivetti \& Ogle 2000). The knowledge on wild vegetables has been developed over the centuries on trial and error basis and pass on to generation after generations mainly through oral communication (Malaisse \& Parent 1985).

Wild edible plants can be used as substitute food at the time of scarcity or in stressed seasons. The demand of wild leafy vegetables is more as compared to other plants because of their availability in large quantities (Reddy et al. 2007; Kar 2004). Nutritional value of these plants are much higher to cultivated green vegetables produced in kitchen gardens or through large scale cultivation in crop fields (Yildirim et al. 2001). The neutraceuticals like minerals, proteins, vitamins, fiber, pigments and other secondary metabolites such as alkaloids, phenolic compounds, gums and resins, essential fatty acids, etc. increase the food-value of diet. They have also medicinal value i.e., antioxidant, antibacterial and anticarcinogenic properties (Heywood 1999).

India is known as one of the four-mega diversity countries of Asia because of two important region viz., the Eastern Himalayas comprising the northeastern part of India and 
the Western Ghats in peninsular India (Ramakrishna 2000). The north-eastern states have many small and large tribes compared to other parts of India, (Agrahur-Murugkar \& Subbulakshmi 2005). While Arunachal Pradesh is dominated by many indigenous ethnic communities endowed with the tropical rain forest and the Himalayan Ecosystem, is a natural storehouse of rich flora and fauna. Most of the species are endangered in this area. Arunachal Pradesh is also one of the hot spots biodiversity in the world (Tag et al. 2008). It is located in $26^{\prime} 28^{\prime}$ to $29^{\prime} 30^{\prime} \mathrm{N}$ latitude and 91'30' to $97^{\prime} 30^{\prime} \mathrm{E}$ longitude with a total population of 13,82,61 (according to 2011 census), covering an area of 83,743 sq Km (Tag et al. 2008; Rethy et al. 2010).There are 26 major tribes and 110 sub-tribes in Arunachal Pradesh. They have their own culture, tradition and ethno-medicinal herbal lore acquired over the centuries (Srivastava 2009).

The Adis are one of the prominent tribes of Arunachal Pradesh living scattered in different districts and pockets, mainly in Upper Siang, East Siang, East and adjacent part of West Siang, Lower Dibang Valley Districts and near Assam-Arunachal border areas (Jha 1985). They are much dependent on wild-edible plants growing in their surroundings. Thick hilly terrain, rain forest, high rainfall and humid climate favour rich flora and form the houses for wild edible plants.

The study was carried out in Kaying circle of Siang District of Arunachal Pradesh, regionally known for rich biodiversity and ethno-cultural diversity. But the area is considered as the store house of rich wild vegetables which are least explored in terms of ethnobotanical and wild edible plant resources (Tag et al. 2007; Ranjay et al. 2007). During the study, an attempt has been made to document the wild leafy vegetables which are used as food in day to day life and confirmed through field survey and literature survey. At the same time, the present work was designed to validate the ethnobotanical claims of five species of wild leafy vegetables for their phytochemical screening so that those could be recommended for future scientific conservation practices, domestic uses and sustainable commercial utilization. The present study enumerated 28 wild leafy vegetables shown in tabular form with botanical name, local name, family, mode of consumption and medicinal uses those have been recorded from the study area.

The five wild leafy vegetables which are selected for nutritional validation are: Spilanthes acmella (L.) L. (Marsang), Zanthoxylum rhetsa DC. (Onger), Pouzolzia hirta Blume ex Hassk. (Oyik), Clerodendrum glandulosum Lindl. (Ongin) and Piper pedicellatum C.DC. (Rori). Leaves of these plants are used as vegetables by the Adi people (Ranjay et al. 2007).

\section{METHODOLOGY}

\section{Field Work}

Apart from intense and inclusive survey of literature, frequent field work was done. The methodology followed during field work was based mainly on a detailed questionnaire prepared on the model by Jain (1987). The field work was carried out from the month of February 2017 to October 2018. The purpose of the study was the collection of first-hand information about the relationship of plants with the local communities. Before each interview, authors and the informant signed a the mendatory PIC through the village Headman (Gaon Burah). The field studies were carried out among the Adi tribes of Kaying areas earlier belonging to the West Siang District and presently relocated in the Siang District. Plant were collected and preserved according to standard field and herbarium techniques (Jain \& Rao 1977). The collected plant specimens were identified with the help of literature including The Flora of 
British India (Hooker 1892 - 1972), Flora of Assam (Kanjilal et al. 1934 - 1940), Flora of China (Fu Liguo et al. 1999), Materials for the Flora of Arunachal Pradesh (Hajra et al. 1996; Giri et al. 2008; Chowdhery et al. 2009) and consultation with regional taxonomists. Further, authentication of identity were confirmed by matching with the authenticated specimens in ARUN Herbarium.

\section{Qualitative Analysis}

The different qualitative chemical tests were performed for establishing profile of given extract for its chemical composition (Raaman 2006). For analysis of the different qualitative chemical tests plant extracts were taken with water, methanol and chloroform. These extracts were then taken for the following tests to detect the various phyto-chemical constituents present in those.

1. For Alkaloids (Evans 1997)
a. Mayer's test
b. Wagner's test
c. Hager's test

2. For Carbohydrates (Ramakrishnan et al. 1994)
a. Molish's test
b. Fehling's test
c. Barfoed's test
d. Benedict's test

\section{For Glycosides}

a. Borntrager's test (Evans 1997)

4. For Saponins (Kokate 1999)

5. For Proteins and Amino acids(Fisher 1968; Ruthmann 1970)

a. Ninhydrin Test (Yasuma \& Ichikawa 1953)

6. For Fixed Oils and Fats (Kokate 1999)
a. Spot Test
b. Saponification Test

7. For Phenolic compounds and Tannins
a. Ferric chloride test (Mace 1963)
b. B.Gelatin test (Evans 1997)
c. Lead acetate test

\section{RESULTS}

\section{Enumeration and Uses of Wild Leafy Vegetables}

Ethnobotanical survey in the Kaying circle of Siang District of Arunachal Pradesh rich in people of Adi community resulted in the recognition of 28 species and is presented here in Table 1.

\section{Statistical Analysis:}




\section{Statistics of Wild Leafy Vegetables Collection}

The total number of 28 plant species were documented which is used as vegetables in food as well as with ethno-medicinal values. Of the total 28 wild leafy vegetables, herbs represent 14 species, which is followed by 11 species of shrubs, 2 species of trees and 1 species of climber (Figure 1).

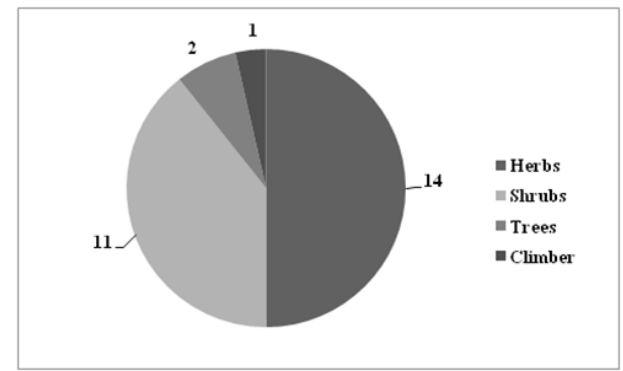

Figure 1. Habit group classification of recognized wild edible species.

\section{Collection Time of Wild Vegetables}

The people of Adi tribes collect wild leafy vegetables in different season of the year (Figure 2 ). They collected the vegetables for their own consumption, selling in the market for the fulfillment of their need of money and also during the food scarcity. However, most of the vegetables they collect during the months of March to May and from August to November.

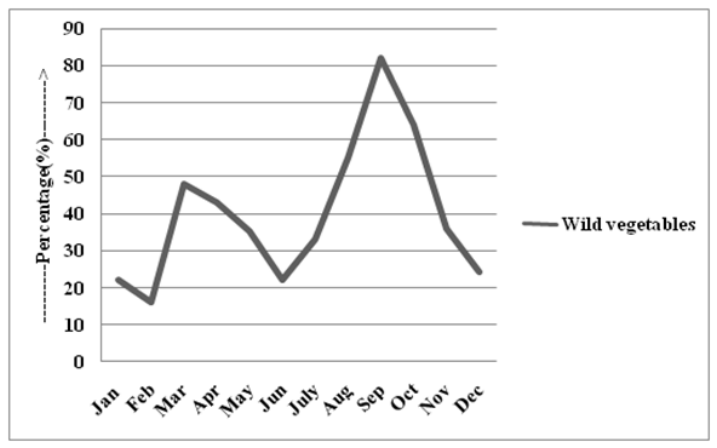

Figure 2. Intensity of collection of wild vegetables in different months of the year

\section{Age and gender group in the collection of Wild Leafy Vegetables.}

To recognise the age and gender groups of collectors, 100 respondents were asked or interviewed, of which 30 were from older group ranges 45 - 65 years (male or female), 40 were younger group ranges 25 - 45 years (male or female) and 30 were youth group ranges 15-25 years (Boys or Girls). The respondent age's ranges from $15-65$ as per the knowledge of the villagers. It is also noted that aged respondents know more about wild leafy vegetables compared to the younger ones that they achieved through their long experiences.

During interviews, it is also revealed that the young generation became less interested in the use of traditional knowledge due to inroad of different facilities of modernization. Statistically, it was found that females, of all age groups, gather much more wild vegetables from the vegetation (Figure 3). 


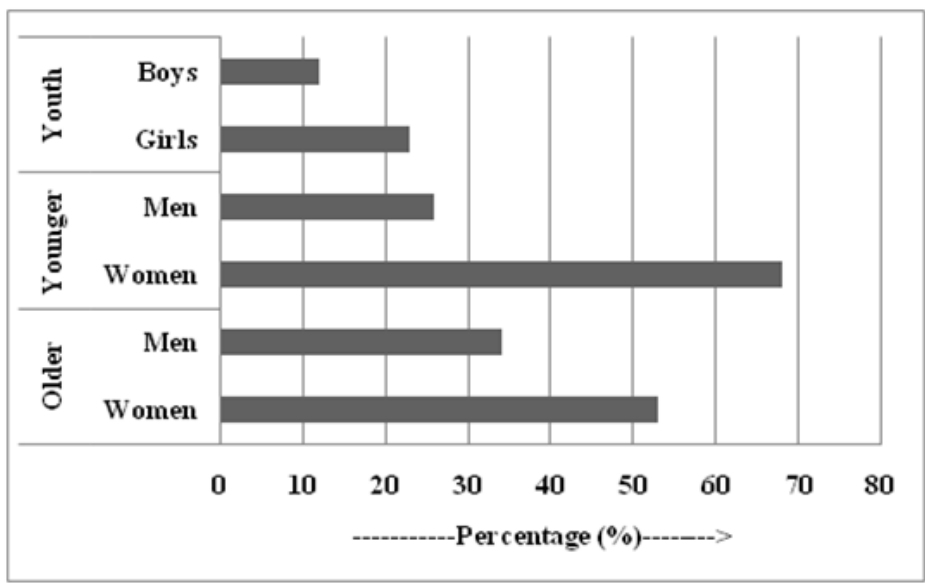

Figure 3. Role of age and gender for the collection of wild edible vegetable

\section{Analysis of Informants knowledge.}

The informants were broadly classified into 4 groups according to knowledge acquired:

Ï\% Through elderly person from village

Ï\% Through family members

Ï\% Through folklore

Ï\% Through scripture, and books

Statical analysis shows that $38.92 \%$ of informants acquired knowledge from their family members since their childhood especially during collection and processing of collected vegetable in field and at home from their seniors in the family. Younger generation also procure knowledge from elderly persons $(32.36 \%)$ from their village and from the surrounding area (Figure 4). Rest from scripture and folklore which contribute less information about $18.76 \%$ and $9.46 \%$ respectively. Since tribe people has no scripture, thus information from the scripture is very less. Most of the information were transfer through oral means only.

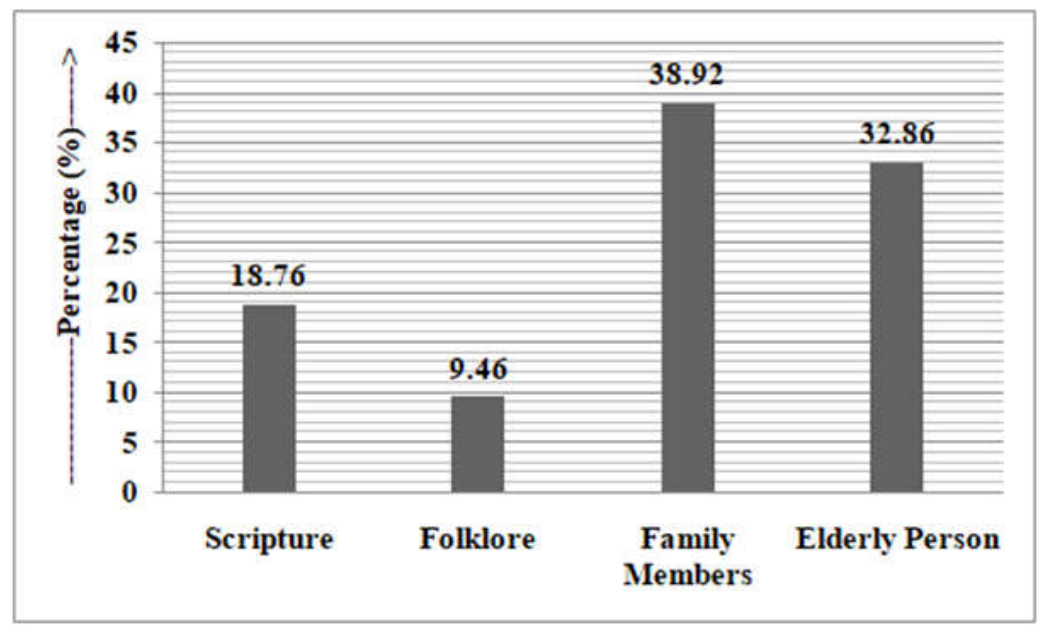

Figure 4: Sources of acquired knowledge. 


\section{Status of wild leafy vegetables in local markets}

The present investigation deals with 28 wild leafy vegetables with their availability in the price at which those are sold. The people of Siang district particularly the Adi tribe are largely dependent on wild plants for their existence; their local markets are full of wild and cultivated vegetables, fruits and medicinal plants.

Wild leafy vegetables have good prospect in the local markets and form one important source for income generation as many people depend on markets to get those vegetables (Table 1). However, the discussion also revealed that some of the wild vegetables are no more available in the vegetation as those are lost due to over exploitation and mutilation of their natural habitat. In the market, most of the wild vegetables are sold on the bundle basis. Weight of these bundles are approximately $100-150 \mathrm{gm}$ and $150-200 \mathrm{gm}$. Some of the vegetables were commonly available in the market and some are rare.

Table 1. List wild edible plants and their status in local markets.

\begin{tabular}{|c|c|c|c|c|}
\hline Plant Name & $\begin{array}{l}\text { Local } \\
\text { name }\end{array}$ & Use & $\begin{array}{c}\text { Market } \\
\text { Price [Rs./ } \\
\text { bundle] }\end{array}$ & $\begin{array}{c}\text { Frequency } \\
\text { of } \\
\text { marketing }\end{array}$ \\
\hline $\begin{array}{l}\text { Baliospermum calycinum Müll.Arg. } \\
{[\text { [Euphorbiaceae]; JamiN- } 021}\end{array}$ & Gilgal & $\begin{array}{l}\text { Leaves as } \\
\text { vegetable }\end{array}$ & 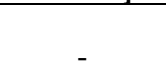 & Rare \\
\hline $\begin{array}{l}\text { Bauhinia variegata } \text { L. [Leguminosae]; } \\
\text { JamiN-023 }\end{array}$ & Ogok & $\begin{array}{l}\text { Tender leaves and } \\
\text { flower buds as } \\
\text { vegetable }\end{array}$ & 20.00 & Common \\
\hline $\begin{array}{l}\text { Begonia griffithiana (A.DC.) Warb. } \\
\text { [Begoniaceae]; JamiN-032 }\end{array}$ & $\begin{array}{l}\text { Sudum } \\
\text { Meko }\end{array}$ & $\begin{array}{l}\text { Leaves as sour } \\
\text { vegetable; boiled } \\
\text { with smoked meat }\end{array}$ & 10.00 & Common \\
\hline $\begin{array}{l}\text { Blumea fistulosa (Roxb.) Kurz } \\
\text { [Compositae]; JamiN-024 }\end{array}$ & Rumdum & $\begin{array}{l}\text { Leaves as } \\
\text { vegetable }\end{array}$ & 10.00 & Rare \\
\hline $\begin{array}{l}\text { Cardamine hirsuta L. [Cruciferae]; } \\
\text { JamiN-008 }\end{array}$ & Tuka & $\begin{array}{l}\text { Leafy shoot as } \\
\text { vegetable }\end{array}$ & 20.00 & Common \\
\hline $\begin{array}{l}\text { Clerodendrum glandulosum Lindl. } \\
\text { [Labiatae]; Jami } N-012\end{array}$ & Ongin & $\begin{array}{l}\text { Tender leaves as } \\
\text { vegetable }\end{array}$ & 20.00 & Common \\
\hline $\begin{array}{l}\text { Elatostema sessile J.R.Forst. \& G.Forst. } \\
\text { [Urticaceae]; JamiN-016 }\end{array}$ & Obur & $\begin{array}{l}\text { Leaves as } \\
\text { vegetable }\end{array}$ & 20.00 & Common \\
\hline $\begin{array}{l}\text { Fagopyrum acutatum (Lehm.) Mansf. ex } \\
\text { K.Hammer [Polygonaceae]; JamiN-014 }\end{array}$ & Okung & $\begin{array}{l}\text { Tender leaves as } \\
\text { vegetables as well } \\
\text { as medicinal value }\end{array}$ & 20.00 & Common \\
\hline $\begin{array}{l}\text { Fagopyrum esculantum Moench } \\
\text { [Polygonaceae]; JamiN-026 }\end{array}$ & $\begin{array}{l}\text { Amintate } \\
k\end{array}$ & $\begin{array}{l}\text { Leaves as } \\
\text { vegetable; ripe } \\
\text { fruits eaten }\end{array}$ & 10.00 & Rare \\
\hline $\begin{array}{l}\text { Glochidion multiloculare (Rottler ex } \\
\text { Willd.) Voigt [Phyllanthaceae]; JamiN-005 }\end{array}$ & $\begin{array}{l}\text { Gaam } \\
\text { Oying }\end{array}$ & $\begin{array}{l}\text { Tender leaves as } \\
\text { vegetable }\end{array}$ & 10.00 & Common \\
\hline $\begin{array}{l}\text { Crassocephalum cripidioides (Benth.) } \\
\text { S.Moore [Compositae]; JamiN-011 }\end{array}$ & $\begin{array}{l}\text { Gende/ill } \\
i\end{array}$ & $\begin{array}{l}\text { Leaves cooked } \\
\text { with roasted meat }\end{array}$ & 20.00 & Common \\
\hline $\begin{array}{l}\text { Gynura cusimbua (D.Don) S.Moore } \\
\text { [Compositae]; JamiN-028 }\end{array}$ & Ogen & $\begin{array}{l}\text { Leaves as } \\
\text { vegetable }\end{array}$ & - & Rare \\
\hline $\begin{array}{l}\text { Houttuynia cordata Thunb. [Saururaceae]; } \\
\text { JamiN-030 }\end{array}$ & Roram & $\begin{array}{l}\text { Whole plant as } \\
\text { vegetable }\end{array}$ & 10.00 & Common \\
\hline $\begin{array}{l}\text { Mussaenda roxburghii Hook.f. } \\
\text { [Rubiaceae]; JamiN-013 }\end{array}$ & Akshap & $\begin{array}{l}\text { Tender leaves as } \\
\text { vegetable }\end{array}$ & 20.00 & Common \\
\hline $\begin{array}{l}\text { Oxalis corniculata } \text { L. [Oxalidaceae]; } \\
\text { Jami } N-033\end{array}$ & Phakep & $\begin{array}{l}\text { Leaves as } \\
\text { vegetable; cures } \\
\text { dysentery }\end{array}$ & 10.00 & Rare \\
\hline
\end{tabular}




\begin{tabular}{|c|c|c|c|c|}
\hline Plant Name & $\begin{array}{l}\text { Local } \\
\text { name }\end{array}$ & Use & $\begin{array}{l}\text { Market } \\
\text { Price [Rs./ } \\
\text { bundle] }\end{array}$ & $\begin{array}{l}\text { Frequency } \\
\text { of } \\
\text { marketing }\end{array}$ \\
\hline $\begin{array}{l}\text { Paederia foetida L. [Rubiaceae]; JamiN- } \\
027\end{array}$ & Yepetare & $\begin{array}{l}\text { Whole plant as } \\
\text { vegetable }\end{array}$ & - & Rare \\
\hline $\begin{array}{l}\text { Piper pedicellatum C.DC. [Piperaceae]; } \\
\text { Jami } N-001\end{array}$ & Rori & $\begin{array}{l}\text { Leaves as } \\
\text { vegetable; }\end{array}$ & 20.00 & Common \\
\hline $\begin{array}{l}\text { Plantago asiatica subsp. erosa (Wall.) } \\
\mathrm{Z.Yu} \mathrm{Li} \mathrm{[Plantaginaceae];} \mathrm{JamiN-034}\end{array}$ & $\begin{array}{l}\text { Doni- } \\
\text { hankang }\end{array}$ & $\begin{array}{l}\text { Whole plant as } \\
\text { vegetable }\end{array}$ & - & Rare \\
\hline $\begin{array}{l}\text { Plantago major L. [Plantaginaceae]; } \\
\text { JamiN-031 }\end{array}$ & $\begin{array}{l}\text { Nane } \\
\text { gitbung }\end{array}$ & $\begin{array}{l}\text { Tender leaves as } \\
\text { vegtables }\end{array}$ & 20.00 & Rare \\
\hline $\begin{array}{l}\text { Portulaca oleracea L. [Portulacaceae]; } \\
\text { JamiN-020 }\end{array}$ & $\begin{array}{l}\text { Gubar } \\
\text { Oying }\end{array}$ & $\begin{array}{l}\text { Leafy shoot as } \\
\text { vegetable }\end{array}$ & 20.00 & Common \\
\hline $\begin{array}{l}\text { Pouzolzia hirta Blume ex Hassk. } \\
\text { [Urticaceae]; JamiN-010 }\end{array}$ & Oyik & $\begin{array}{l}\text { Leafy shoot as } \\
\text { vegetable }\end{array}$ & 30.00 & Common \\
\hline $\begin{array}{l}\text { Sida acuta Burm.f. [Malvaceae]; JamiN- } \\
025\end{array}$ & Tanngom & $\begin{array}{l}\text { Leaves as } \\
\text { vegetable }\end{array}$ & - & Rare \\
\hline $\begin{array}{l}\text { Solanum americanum Mill. [Solanaceae]; } \\
\text { JamiN-009 }\end{array}$ & Yang-ga & $\begin{array}{l}\text { Leafy shoot as } \\
\text { vegetable; berries } \\
\text { eaten raw or } \\
\text { cooked }\end{array}$ & 10.00 & Common \\
\hline $\begin{array}{l}\text { Sonchus oleraceus (L.) L. [Compositae]; } \\
\text { JamiN-035 }\end{array}$ & Ogon & $\begin{array}{l}\text { Tender leaves as } \\
\text { vegetable as well } \\
\text { as chutti }\end{array}$ & - & Rare \\
\hline $\begin{array}{l}\text { Spilanthes acmella (L.) L. [Compositae]; } \\
\text { JamiN-003 }\end{array}$ & Marsang & $\begin{array}{l}\text { Leaves as } \\
\text { vegetable; cures } \\
\text { oral diseases in } \\
\text { cattle }\end{array}$ & 10.00 & Common \\
\hline $\begin{array}{l}\text { Spiradiclis bifida Kurz [Rubiaceae]; } \\
\text { JamiN-029 }\end{array}$ & Sokho & $\begin{array}{l}\text { Leaves as } \\
\text { vegetable }\end{array}$ & - & Rare \\
\hline Urtica dioica L. [Urticaceae]; JamiN-022 & $\begin{array}{l}\text { Osut- } \\
\text { Oyit }\end{array}$ & $\begin{array}{l}\text { Leaves as } \\
\text { vegetable }\end{array}$ & 20.00 & Rare \\
\hline $\begin{array}{l}\text { Zanthoxylum rhesta DC. [Rutaceae]; } \\
\text { JamiN-004 }\end{array}$ & Onger & $\begin{array}{l}\text { Leaves as } \\
\text { vegetable }\end{array}$ & 20.00 & Common \\
\hline
\end{tabular}

\section{Wild leafy vegetables used also in ethno-medicines}

The present investigation revealed that out of 28 recognized wild leafy vegetable species, 15 has ethnomedicinal importance for the people of Adi tribe of Siang District (Table 2). The species reported are used to heal pain and inflammation such as rheumatic swelling, cuts and wounds, accidental bone fracture, boils and eruptions, blood purification, loss of appetite, dysentery, diarrhea, constipation, poor milk secretion in lactating mother and as diuretic.

Further, it is revealed that both male and female folks have good knowledge on village medico-botany and herbal formulation for treating various ailments. However, these kinds of traditional knowledge are restricted to a few individual only in society. Due to modernization and lack of interest, this kind of knowledge does not inherit to next generation.

\section{Qualitative Phytochemical Screening}

The phytochemical screening test was done on the selected five species of plants, namely: Spilanthes acmella (Marsang, S-1), Zanthoxylum rhetsa (Onger, S-2), Pouzolzia hirta (Oyik, S-3), Clerodendrum glandulosum (Ongin, S-4) and Piper pedicellatum (Rori, S5). The plant extract was prepared from sun-dried plant samples using Chloroform, Methanol and Water as solvents and were taken for various tests. Results of such tests has been presented in Table 3. 
Table 2. Ethno-medicinal uses of wild edible vegetables

\begin{tabular}{|c|c|c|}
\hline Plant Name & Local name & Medicinal Uses \\
\hline Blumea fistulosa & Rumdum & Diarrhea \\
\hline Clerodendrum glandulosum & Ongin & Blood Pressure \\
\hline Fagopyrum acutatum & Okung & $\begin{array}{l}\text { Arthritis; vermicidal; colic; choleric; diarrhea; } \\
\text { abdominal obstructions }\end{array}$ \\
\hline Mussaenda roxburghii & Akshap & Mouth ulcer; increase appetite; cuts and wounds \\
\hline Oxalis corniculata & Phakep & Anti-dysenteric; relieve intoxication from wine \\
\hline Paederia foetida & Yepetare & Indigestion; dysentery; diarrhea \\
\hline Piper pedicellatum & Rori & Fruits used for stomach disorder \\
\hline Plantago asiatica subsp. erosa & $\begin{array}{l}\text { Doni- } \\
\text { hankang }\end{array}$ & Constipation; improves digestion \\
\hline Plantago major & $\begin{array}{l}\text { Nane } \\
\text { gitbung }\end{array}$ & $\begin{array}{l}\text { Boils; burns and inflammation; } \\
\text { dysentery and diarrhea; cough }\end{array}$ \\
\hline Portulaca oleracea & $\begin{array}{l}\text { Gubar } \\
\text { Oying }\end{array}$ & Stomachic \\
\hline Pouzolzia hirta & Oyik & Increase lactation in woman \\
\hline Solanum americanum & Yang-ga & Digestive; liver tonic \\
\hline Sonchus oleraceus & Ogon & Flatulence and body pain \\
\hline Spilanthes acmella & Marsang & Toothache; fever; mouth diseases in cattle \\
\hline Zanthoxylum rhesta & Onger & $\begin{array}{l}\text { Stomach bloating; pregnancy termination; } \\
\text { anti-helminthic }\end{array}$ \\
\hline
\end{tabular}

Table 3. Phytochemical screening test in different solvents [S-1 Spilanthes acmella; $\mathbf{S}-\mathbf{2}$ Zanthoxylum rhetsa; S-3 Pouzolzia hirta; S-4 Clerodendrum glandulosum; S-5 Piper pedicellatum]

\begin{tabular}{|c|c|c|c|c|c|c|c|c|c|c|c|c|c|c|c|}
\hline \multirow[t]{2}{*}{$\begin{array}{l}\text { Phytochemical } \\
\text { Test }\end{array}$} & \multicolumn{5}{|c|}{ Chloroform } & \multicolumn{5}{|c|}{ Methanol } & \multicolumn{5}{|c|}{ Water } \\
\hline & S-1 & S-2 & S-3 & S-4 & S-5 & S-1 & S-2 & $S-3$ & S-4 & S-5 & S-1 & S-2 & S-3 & S-4 & S-5 \\
\hline \multicolumn{16}{|l|}{ 1. Alkaloids } \\
\hline a) Mayer's Test & + & + & + & + & + & ++ & + & ++ & + & + & + & + & + & + & ++ \\
\hline b) Wagner's Test & ++ & ++ & ++ & + & + & + & + & ++ & + & + & + & + & + & + & + \\
\hline c) Hager's Test & ++ & + & - & + & + & ++ & ++ & ++ & + & + & + & + & + & ++ & + \\
\hline \multicolumn{16}{|c|}{ 2. Carbohydrates and gylcosides } \\
\hline a) Molish's Test & + & - & - & - & - & - & ++ & ++ & ++ & + & +++ & + & + & ++ & ++ \\
\hline b) Fehling's Test & +++ & ++ & ++ & ++ & ++ & + & + & + & + & + & + & ++ & ++ & + & + \\
\hline c) Barfoed's Test & - & - & - & - & - & - & - & - & - & - & - & - & - & - & - \\
\hline $\begin{array}{l}\text { d) Benedict's } \\
\text { Test }\end{array}$ & ++ & ++ & +++ & ++ & ++ & - & + & + & - & - & ++ & + & + & +++ & ++ \\
\hline $\begin{array}{l}\text { e) Borntrager's } \\
\text { Test }\end{array}$ & - & - & - & - & - & - & - & - & - & - & - & - & - & - & - \\
\hline \multicolumn{16}{|l|}{ 3.Saponins } \\
\hline a) Foam Test & - & - & - & - & - & + & - & +++ & + & + & + & + & - & ++ & ++ \\
\hline \multicolumn{16}{|c|}{ 4. Protein \& Amino acid Test } \\
\hline $\begin{array}{l}\text { a) Ninhydrin } \\
\text { Test }\end{array}$ & - & ++ & ++ & ++ & ++ & - & + & + & ++ & ++ & - & + & + & - & - \\
\hline \multicolumn{16}{|c|}{ 5. Fixed Oils and Fats } \\
\hline a) Spot Test & + & + & + & + & + & + & + & + & ++ & + & + & + & + & + & + \\
\hline $\begin{array}{l}\text { b) Saponification } \\
\text { Test }\end{array}$ & - & - & - & - & - & - & - & - & - & - & - & - & - & - & - \\
\hline
\end{tabular}




\begin{tabular}{|c|c|c|c|c|c|c|c|c|c|c|c|c|c|c|c|}
\hline \multirow[t]{2}{*}{$\begin{array}{l}\text { Phytochemical } \\
\text { Test }\end{array}$} & \multicolumn{5}{|c|}{ Chloroform } & \multicolumn{5}{|c|}{ Methanol } & \multicolumn{5}{|c|}{ Water } \\
\hline & S-1 & S-2 & S-3 & S-4 & S-5 & S-1 & S-2 & S-3 & S-4 & S-5 & S-1 & S-2 & S-3 & S-4 & S-5 \\
\hline \multicolumn{16}{|c|}{ 6. Phenolic Compounds and Tannins } \\
\hline $\begin{array}{l}\text { a) Ferric } \\
\text { chloride Test }\end{array}$ & + & + & + & + & + & + & ++ & ++ & +++ & +++ & - & ++ & + & + & - \\
\hline b) Gelatin Test & - & - & - & - & - & + & ++ & + & + & + & - & - & - & - & - \\
\hline $\begin{array}{l}\text { c) Lead acetate } \\
\text { Test }\end{array}$ & - & - & - & - & - & ++ & + & + & ++ & + & ++ & + & + & +++ & +++ \\
\hline \multicolumn{16}{|c|}{ 7. Gums and Mucilages } \\
\hline $\begin{array}{l}\text { a) Alcohol 95\% } \\
\text { Test }\end{array}$ & - & - & - & - & - & - & - & - & - & - & + & - & - & ++ & ++ \\
\hline
\end{tabular}

$*_{\text {-ve }}=$ Absent and $+\mathrm{ve}=$ Present

\section{DISCUSSION AND CONCLUSION}

After the field study it was realized that the people of Adi tribe do have vast knowledge about the wild leafy vegetables those are found in their surrounding areas. Their knowledge about the wild leafy vegetables for culinary or in other uses is highly appreciable. It is evident from the study that the Adi tribes have been using these wild leafy vegetables since time immemorial.

It was found that the wild species is used much more than the cultivated ones because the wild plants are available in abundance in forests and other type of vegetation. Most of those are perennial and can also available in unfavorable conditions such as famine, drought, flood, etc.

Further analysis revealed that the women of Adi tribes were much knowledgeable as compared to male folk whether in collection, utilization of plant parts or in treating ailments. The reason behind this is because they have major role in cooking and management of kitchen to ensure nutritional balance of the family members.

The local market survey revealed that a large number of wild leafy vegetables and few cultivated plants are sold in local markets throughout the year. Thus, the economy of ethnic communities is also dependent on trade of minor wild vegetable products in the local markets. In the times of scarcity like crop failure, drought, famines etc. such wild food plants are the ultimate sources of survival. The indigenous knowledge on ethno-medicine is also prevalent among the Adi tribe since time immemorial. They have their own traditional way of curing the diseases.

Qualitative phytochemical analysis has revealed that alkaloids were present in almost all the five plant species which was confirmed by different solvents such as chloroform, methanol and water. However, S. acmella shows highest concentration of alkaloids, followed by $P$. hirta, Z. rhetsa, C. glandulosum, and P. pedicellatum as shown in Table 3.

Again, S. acmella shows highest concentration of carbohydrates and glycosides with C. glandulosum, followed by $P$. hirta, $P$. pedicellatum and $Z$. rhetsa.

The saponins were present in three plant species only i.e. P. hirta, C. glandulosum, and $P$. pedicellatum in which highest concentration was confirmed in $P$. hirta. The saponin concentration was almost nil in two species i.e. S. acmella and Z. rhetsa. Confirmation of saponins in chloroform extract showed negative result.

The presence of proteins and amino acids in four plant species was confirmed by chloroform extract, was better as compared to other extracts. S. acmella showed negative 
result in all the three extract that ask for some other methodology. Oils and fats are present in almost all the plant species with higher concentration in C. glandulosum.

In chloroform extracts, phenolic compounds and tannins show negative results while in methanol and water extracts plant species show positive confirmation with highest concentration in C. glandulosum followed by P. pedicellatum, Z. rhetsa, S. acmella and P. hirta respectively.

Presence of gums and mucilage in plant species show negative results in both the chloroform and methanol extracts but in water extract it was found in C. glandulosum, $P$. pedicellatum, and S. acmella while absence in $Z$. rhetsa and $P$. hirta.

However, the entire survey, including the phytochemical analysis proved that the nutritional status of the wild edible vegetables is quite good and are also appreciated by the people of Adi community. But, if some of these plants like Clerodendrum glandulosum, Zanthoxylum rhetsa and Piper pedicellatum may be cultivated as their demand in markets is quite high.

\section{Acknowledgements}

The authors are thankful to the Head, Department of Botany, Rajiv Gandhi University for giving kind permission and providing necessary facilities. The authors are also grateful to Dr. A.P. Das, Visiting Professor, Rajiv Gandhi University for his generous help in identification of plants.

\section{LITERATURE CITED}

Agrahar-Murughar, D. \& Subbulakshmi, G. 2005. Nutritive values of Wild Edible Fruits, Berries, Nuts, Roots and Spices consumed by the Khasi tribes of India. Ecol. Food Nutri. 44: 207 - 223.

Chowdhery, H.J.; Giri, G.S. \& Pramanik, A. 2009. Materials for the Flora of Arunachal Pradesh. Vol. III. Botanical Survey of India, Calcutta.

Evans, W.C. 1997. Pharmacology. Harcount Brace and Company, Asia, Singapore. Pp. $226-228$.

Fisher, D.D. 1968. Protein staining of robboned epon section for light microscopy. Histochem. $16: 81-96$.

Giri, G.S.; Pramanik, A. \& Chowdhery, H.J. 2008. Materials for the Flora of Arunachal Pradesh. Vol. II. Botanical Survey of India, Kolkata.

Grivetti, L.E. \& Ogle Britta, M. 2000. Value of traditional foods in meeting macro-and micronutrient needs: the wild plant connection, Natl. Res. Rev. 13: $31-46$.

Hajra, P.K.; Verma, D.M. \& Giri, G.S. 1996. Materials for the Flora of Arunachal Pradesh. Vol. I. Botanical Survey of India, Calcutta.

Heywood, V. 1999. FAO Farm systems Management Series-15.Use and potential of wild plants in farm households. FAO corporate Repository.

Hooker, J.D. 1892-1972. The Flora of British India; Vols. I - VII. L.Reeve \& Company, Convent Garden, London.

Jain, S.K. 1987. A Manual of Ethnobotany. Scientific Publisher, Johdpur.

Jain, S.K. \& Rao, R.R. 1977. A Hand Book of Field and Herbarium Techniques, Today and Tomorrows Publishers, New Delhi. Pp.30-45.

Jha, S.D. 1985. The wealth of Arunachal Pradesh. Mittal Publication, Delhi. 
Kanjilal, U.N.; Kanjilal, P.C.; Das, A.R.N. \& Bor, N.L. 1934-1940. Flora of Assam. Vol.15. Assam Govt. Press, Shillong. [Reprint: Omsons Publication, New Delhi]

Kar, A. 2004. Common wild vegetables of Aka tribe of Arunachal Pradesh. Indian J. Trad. Knowl. 3(3): $305-313$.

Liguo, F.; Yong-fu, Y. \& Herald R. 1999. Flora of China, Vol 4. Beijing: Science Press; St. Louis: Missouri Botanical Garden.

Mace, M.E. 1963. Histochemical Localization of phenols in healthy and diseased tomato roots. Phytopathology, 16: 915 - 925.

Maikhuri, R.K.; Rao, K.S. \& Saxena, K.S. 2004. Bioprospecting of Wild Edibles for rural Development in the Central Himalayan Mountains of India. Mount. Res. Dev. 24(2): $110-113$.

Malaisse, F. \& Parent, G. 1985. Edible Wild vegetables products in the Zambezian woodland area: A nutritional and ecological approach. Ecol. Food Nutri. 18: 43 - 82.

Raaman, N. 2006. Phytochemical Techniques, New Delhi Publishing.

Ramakrishna, P.S. 2000. Biodiversity, land use and traditional ecological knowledge: The context. Mountain Biodiversity, Land use Dynamics and Traditional Ecological Knowledge. Oxford and IBH Publication, New Delhi. Pp. 3 - 13.

Ranjay, K.S.; Anamika, S.; Hui, T. \& Adi Community. 2007. Traditional Skill among the Adi Tribes of Arunachal Pradesh. Indian J. Trad. Knowl. 7(1): 27 - 36.

Reddy, B.M. 2012. Wild edible plants of Chandrapur district, Maharashtra, India. Indian J. Nat. Prod. Resorc. 3 (1): 110 - 117.

Reddy, K.N.; Pattanaik, C.; Reddy, C.S. \& Raju,V.S. 2007. Traditional knowledge on wild food plants in Andhra Pradesh. Indian J. Trad. Knowl. 6(1): 223 - 229.

Rethy, P.; Singh, B.; Kagyung, R. \& Gajurel, P.R. 2010. Ethanobotanical studies of DehangDebang Biosphere Reserve of Arunachal Pradesh with special reference to Memba tribe. Indian J. Trad. Knowl. 9(1): $61-67$.

Ruthmann, A.C. 1970. Methods in cell Research. Cornell University Press, New York, USA

Srivastava, R.C. 2009. Traditional knowledge of Adi tribe of Arunachal Pradesh on plants. Indian J. Trad. Knowl. 8(2): 146 - 153.

Sundriyal, M. \& Sundriyal, R.C. 2001. Wild edible plants of the Sikkim Himalaya: Nutritive value of selected species. Econ. Bot. 55: $377-390$.

Tag, H.; Das, A.K.; Pallabi, H.; Ranjay, K.S. \& Palit, G. 2007. Botanical resources used in traditional wood carving industry among the Wancho tribe of Arunachal Pradesh. Indian J. Trad. Knowl. 7(1): $148-156$.

Tag, H.; Murtem, G.; Das, A.K. \& Singh, R.K. 2008. Diversity and distribution of ethnomedicinal plants used by the Adi tribe in East Siang district of Arunachal Pradesh, India. Pleione 2(1): 123 - 136.

Yasuma, A. \& Ichikawa. 1953. Ninhydrin-schiff and alloxan-schiff staining. A new histochemical staining methods for proteins. J. Lab. Clini. Med. 44: 296 - 299.

Yesodharan, K. \& Sujana, K.A. 2007. Wild edible plants traditionally used by the tribes in the Parambikulam Wildlife Sanctuary, Kerala, India. Nat. Prod. Rad. 6(1): $74-80$.

Yildirim, E.; Dursun, A. \& Turan, M. 2001. Determination of the nutrition of the wild plants used as vegetables in Upper Coruh Valley, Turk. J. Bot. 25: 367 - 371. 